\title{
Implementation of a Monitoring System in the Educational Process in Primary School
}

\author{
Olha A. Komar* \\ Professional Methodologies and Innovative Technologies in Primary School \\ Department, Primary Education Faculty \\ Pavlo Tychyna Uman State Pedagogical University \\ Uman, Ukraine \\ Oleh S. Komar \\ English Language and Methods of its Teaching Department \\ Foreign Languages Faculty, Pavlo Tychyna Uman State Pedagogical University \\ Uman, Ukraine \\ Natalia A. Kolomiiets \\ Education Technologies and Pedagogic Creativity Department, \\ Primary Education Faculty, Pavlo Tychyna Uman State Pedagogical University \\ Uman, Ukraine \\ Liudmyla M. Roienko \\ Professional Methodologies and Innovative Technologies in Primary School \\ Department, Primary Education Faculty, \\ Pavlo Tychyna Uman State Pedagogical University \\ Uman, Ukraine \\ Pavlo V. Diachuk \\ Primary Education Theory Department \\ Primary Education Faculty, Pavlo Tychyna Uman State Pedagogical University \\ Uman, Ukraine
}

\begin{abstract}
The purpose of this study is to explore how primary school teachers perceive the practice of implementing monitoring support on the basis of autonomous monitoring groups by educational level, and what factors have a decisive influence on their positive or negative perception of the above approach to assessing educator/student effectiveness. Several tools were used to collect the data, including: classroom observations, lesson checklists (evaluation forms), lesson plans evaluation forms, interviews for teachers and parents, focus group survey questionnaires. The quantitative data were analysed and
\end{abstract}

*Corresponding author e-mail: borysyakymchuk@yahoo.com 
consolidated in tables, represented as row percentages, and calculated using the Chi-Square statistical method. In addition, the data comparison strategy, triangulation of data sources, and study validation method were used. The Textalyzer web tool was used to process the data obtained through the focus group survey. Focus group teachers spoke positively about the format and content of the project. The majority of the teachers who had formed the experimental group reported improvements in self-organization and self-discipline, flexibility in problem-solving, teamwork skills, and improved learning process engagement and learning outcomes of their pupils. The study illustrated the initial stage of implementation of a monitoring system in the educational process by primary school teachers in Ukraine. The research conditions, constraints and contextual factors that influenced teachers' perception of this innovation were identified. This monitoring system helps to optimize the quality of education in primary school. Teachers reported that by participating in the project, they upgraded their professional skills, improved both their pedagogical mastery and selfstudy skills, increased their self-esteem and motivation. The colleagues' and headteachers' feedback and criticism are often perceived as discouraging factors. The results of the study can be regarded as a baseline due to several limitations, which include a number of participants, potential bias in school choice and limited availability for observation.

Keywords: monitoring support; educational process; primary schools; autonomous monitoring group.

\section{Introduction}

The solution of the problem of implementation of monitoring support in the educational process in primary school is key and urgent for Ukraine in view of the implementation of the conceptual framework for reforming secondary school "New Ukrainian School” (Grischenko, 2016).

Adequate, comprehensive and ongoing monitoring is a key aspect of the successful implementation of any educational program (Environmental Change Institute, 2014; Sima, 2006; Bibik, 2017; Grischenko, 2016). And every time any educational program or subject is implemented, there is a need for a mechanism to assess its effectiveness. Such a mechanism is commonly called monitoring. Within the education system, monitoring involves inspection and control, namely: ongoing, intermediate and final assessments to identify progress in the achievement of learning goals by pupils (Law of Ukraine \# 2145-VIII, 2017, Article 1), is used as a synonym for the term "audit" (internal or external), and is interpreted as a tool of education quality assurance (Law of Ukraine \# 2145-VIII, 2017). In scientific sources, the term "monitoring" is defined as a system of ongoing, interim and summary evaluation (Mertens, 2009, pp. 45-47), a data collection process (Mishra, 2005), a type of evaluation based on the collection of specific information (Noh, 2006).

Monitoring is based on and influences the implementation of educational policy, objectives, educational plans; determines timeliness of decision-making, 
provides accountability and bases for evaluation, as effective monitoring of the educational process integrates information at all levels and provides management, and ultimately the governing body, with insight into the results of educational activity of a particular educational institution and facilitates managerial and other decision-making by stakeholders of the educational process (Marriott \& Goyder, 2009).

The literature review allowed us to identify scientific sources that cover the categorical framework for education monitoring (Hoover, 2009; Mngomezulu, 2015; Ferdaus, 2016), the principles of monitoring in the primary school education process (Kayani, et al, 2011; Mngomezulu, 2015; Ferdaus, 2016), and the impact-factors to its effectiveness (Kayani, et al, 2011; Mngomezulu, 2015; Fulton, 2018).

Our study found three types of a monitoring system specified by their purpose. Those were compliance monitoring (to ensure that certain formal standards of education are met), diagnostic monitoring (to determine effort-cost ratio in measuring pupils' educational achievements) and performance monitoring (to compare schools and educational districts) (Ferdaus, 2016). Additionally, we discovered that every type is based on the further outlined stages (as suggested by Hoover (2009)) being exploratory (identification and selection of what and how to monitor and assess, and designing a monitoring schedule), implementation (activities aimed at checking parameters, assessing the performance and progress) and reflexion (making changes and improvements).

Monitoring system plays an important role in the implementation of all projects, programs and policy areas. In Ukraine, monitoring is conducted "to identify and track trends in the quality of education...; establishment of conformity of actual results of educational activity with the stated goals, estimation of degree and reasons of deviations from the goals" (Order of the Ministry of Education and Science of Ukraine, 2019).

The monitoring system (monitoring support) in the education system in general and the school system in particular, is being implemented as a tool to determine the effectiveness of educational programs and, due to the need to provide information to all education stakeholders on the effectiveness and quality of educational programs (Fegan \& Field, 2009). A monitoring system is much more than just data collection, as it allows avoiding the "closed loop" of poor reliability and poor quality (Mishra, 2005).

Luginbuhl, Webbink and Wolf (2009) point out that school improvement is a constant challenge for the latter. Effective monitoring is an important component of learning activities and, ultimately, a rational educational initiative in the long run (Marriott \& Goyder, 2009). In primary school, the monitoring support system enhances the effectiveness of both teachers and pupils (Miller, 2017), and, in Ukraine's comprehensive schools, monitoring is aimed at solving a number of problems, such as: first, to identify and record the status of educational achievements of elementary school graduates, the volume of their residual 
knowledge and skills before transitioning to secondary school; second, to determine the compliance of pupils' competences with the curriculum for elementary school; third, identify the factors that influence pupils' learning results; fourth, to identify urgent issues and provide a basis for managerial decision-making (UCEQA, 2017).

In most developed countries, the mechanism of monitoring the quality of the educational system has been operating for quite a long time and powerfully.

In Ukraine, at the state level, the external monitoring system for the primary education quality assessment takes place is being implemented in four stages: in 2018, 2020, 2022 and 2024, and it is being implemented on a top-down basis. The procedure of the measure includes test tasks and questionnaires. The purpose of the test tasks is to assess the level of competence development, and the questionnaires (UCEQA, n./d.) - the characteristics and pupil's personal vision of his/her own social and educational activities. The test tasks were developed based on productive foreign experience in comparative education quality studies: PIRLS (Progress in International Reading Literacy Study) and TIMSS (The Trends in International Mathematics and Science Study for fourth- and eighth-formers (UCEQA, 2018).

At the local level, staff at all levels, such as Head of the (District) Department of Education (Methodological Office), methodologists of the District Department of Education (Methodological Office), School Director, Heads (of Sections) of Different Directions of School Activities, teachers (according to their job descriptions) are tasked with regularly attending and observing classroom activities. However, the actual practice of the local level is different from that declared one.

Although the system of monitoring (monitoring support) of primary education is quite well provided with the rules, recommendations and instructions, the educational staff and teachers involved apply them in current practice very rarely and nominally. All of these employees, even the Department Methodologist and Director of Studies, despite his/her duties, attend classes only once or twice a year, although this is required on a regular basis. As a rule, monitoring data is collected at the offices of Directors of Studies, and such data are provided upon results of observation. And, when the quality of teacher teaching is not controlled, they usually do not make lesson plans and use manipulation to justify themselves. This situation leads to a decrease in pupil activity in the classroom and a loss of interest in attending lessons. Therefore, poor monitoring support practices in primary school education processes affect the quality of teaching, which affects the quality of pupils' education in the long run.

Given that the quality of teaching depends on feedback from colleagues and education administrators involved in monitoring (monitoring support), if the teaching staff lacks constructive sincerity and confidence, this has a negative effect on school performance. In addition, the introduction of a monitoring 
system in elementary school based on the creation of autonomous monitoring teams by level of education, so that primary school teachers have the opportunity to regularly receive feedback on their pedagogical activity and improve it is, in our opinion, the optimal solution.

Therefore, the objective of this study was to explore how primary school teachers perceive the practice of implementing monitoring support on the basis of autonomous monitoring groups by educational level, and what factors have a decisive influence on their positive or negative perception of the above approach to assessing educator/student effectiveness.

\section{Methods}

Most of the empirical studies on this issue that we have considered have used a quantitative approach to analyzing the results. Without diminishing their value, we believe that the quantitative approach cannot adequately illustrate all the complexity inherent in changes in educational processes $(\mathrm{Hu}, 2002)$. Therefore, in this study, we used quantitative and qualitative approaches to reveal the contextual and dynamic nature of the primary school teacher's experience in monitoring (monitoring support) of educational activities at the specified educational level (Creswell \& Poth, 2018). It was a one-year study which involved four schools located in deferent regions of Ukraine.

The experiment consisted of two stages: conceptual and experimental. The first stage was implemented during the second half of 2018 and aimed at determining the achievements and approval of a monitoring support system for use in the primary school education process that would take into account the interests and meet the goals of all stakeholders in the educational process. In addition, some preparatory actions were undertaken at this stage, including: development of the requirements for providing feedback and criteria for assessing the quality of the class attended, lesson summary, scoring pupils' (oral and written) answers, instructional and methodological materials for monitoring, questionnaires for teachers on their perceptions of monitoring practices and factors that have a decisive impact on their positive or negative perception of this measure. These materials were developed under the expert assistance of a specialist in the field of pedagogy of primary school Martynenko Svitlana Mykolaivna, Doctor of Pedagogical Sciences, Professor.

The experimental stage began immediately after obtaining permission for conducting research from the District Departments of Education in Kyiv (Pecherskyi district), Odesa (Territorial Department of Education of the Prymorskyi district of the Department of Education and Science of the Odesa City Council), Ternopil (the Department of Education of the Ternopil District State Administration) and Kharkiv (the Department of Education of the Kharkiv City Council), and lasted for the first half of 2019. At this stage, a sample of teachers who responded to an official request from the Departments of Education and declared their participation in our study (a total of 87 people) was formed. The criteria for further selection were pedagogical experience (1-6 years), age (up to 35 years), and the form of ownership of the educational 
institution (for our study - only government-owned), gender (in primary school traditionally only female). Of 32 teachers remaining after applying these criteria, 16 were involved in this study by random sampling and calculation of a representative sample (see Table 1). Prior to the experiment, training on the basics of monitoring was delivered to the teachers involved in the experiment.

Table 1: Additional information about experiment participants

\begin{tabular}{|c|c|c|c|c|c|c|}
\hline $\begin{array}{l}\text { School } \\
\text { Code }\end{array}$ & $\begin{array}{l}\text { Teacher } \\
\text { Code }\end{array}$ & $\begin{array}{l}\text { Pedagogical } \\
\text { experience }\end{array}$ & $\begin{array}{l}\text { Class where } \\
\text { the Teacher } \\
\text { Works }\end{array}$ & $\begin{array}{l}\text { Availability } \\
\text { of the Lesson } \\
\text { Plans }\end{array}$ & $\begin{array}{l}\text { Attending } \\
\text { Lessons }\end{array}$ & $\begin{array}{l}\text { Previous } \\
\text { monitoring } \\
\text { experience }\end{array}$ \\
\hline \multirow[t]{4}{*}{ A } & 1 & 2 & 1 & & $X$ & Yes \\
\hline & 2 & 4 & 2 & $X$ & & No \\
\hline & 3 & 3 & 3 & $X$ & & No \\
\hline & 4 & 3 & 2 & & & No \\
\hline \multirow[t]{5}{*}{$B$} & 5 & 4 & 1 & & & No \\
\hline & 6 & 5 & 3 & $X$ & & No \\
\hline & 7 & 5 & 3 & & & No \\
\hline & 8 & 4 & 2 & $X$ & & Yes \\
\hline & 9 & 6 & 2 & & $X$ & No \\
\hline \multirow[t]{3}{*}{$\mathrm{C}$} & 10 & 3 & 1 & & & No \\
\hline & 11 & 2 & 3 & $X$ & $X$ & No \\
\hline & 12 & 5 & 3 & & & No \\
\hline \multirow[t]{4}{*}{ D } & 13 & 3 & 4 & $X$ & & Yes \\
\hline & 14 & 4 & 4 & & & No \\
\hline & 15 & 6 & 3 & & & No \\
\hline & 16 & 13 & coordinator & $X$ & $X$ & Yes \\
\hline
\end{tabular}

As shown in the chart (see Figure 1), the study was conducted in several stages: preparatory (goal-setting), introductory (monitoring and obtaining results) and reflexive (making adjustments to goals, measures and monitoring tools) and was of cyclical type. 


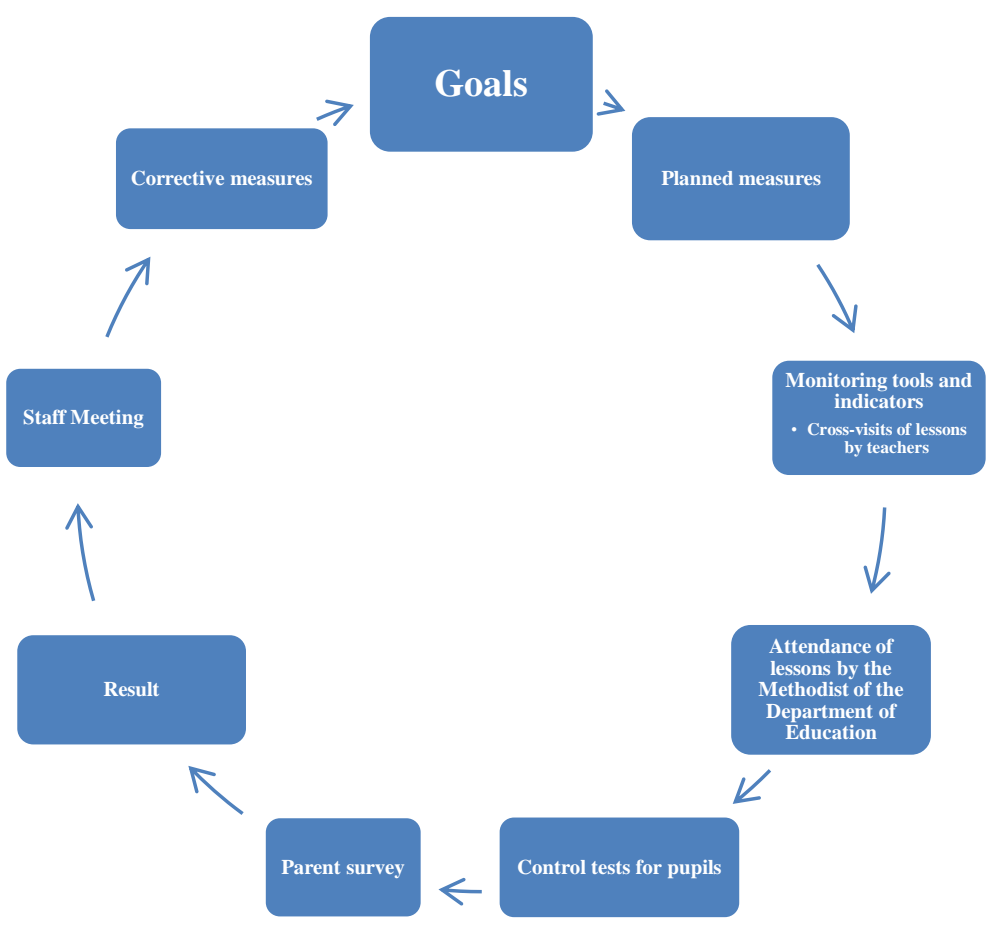

Figure 1: Monitoring support implementation cycle by primary school teachers

As for the lessons, Director of Studies was supposed to attend will attend lessons of a particular teacher each week for observation and providing feedback. Teachers were also paired for cross-attending purposes. Every two weeks, teachers had a meeting with the Director of Studies to discuss the progress of the project and report on the results at the school's staff meeting for obtaining peer review and recommendations. Once a month the lessons were attended by the Methodist of the Department of Education (Methodological Office).

Monitoring indicators included: the number of lesson plans designed, the number and quality of the materials used during the lesson, and whether those materials and tasks met the requirements of Howard Gardner's Multiple Intelligence Theory, the number of cross-attendings, and the attendance of lessons by Director of Studies. The monitoring effectiveness was then evaluated by the Pedagogical Council of a school-participant on the basis of the data, as well as a survey of teachers.

The objects of this study were teachers of government-owned schools in Kyiv, Odesa, Ternopil and Kharkiv. A total number of people involved in the experiment was 87 - a sample was formed using a random sampling method from those teachers who wished to participate. The specified number of persons was further reduced by 55 persons due to the application of exclusion criteria, namely: the form of ownership of the educational institution, teaching experience, and amounted to 32 persons.

A sample size calculator (Google Apps) was used to determine the size of a representative sample to ensure the quality and reliability of the experiment results. Given that $n$ (population) $=32$, confidence interval $=7.18$, and $e=0.1$, if 
confidence coefficient $=95 \%(=$ alpha 0.05$)$. Therefore, the required sample size was 16 people, and this number was used to form a representative sample.

Several data collection tools recommended for qualitative and quantitative studies were applied in this research (Stake, 1995), namely: classroom observations, lesson checklists (evolutionary forms), study of lesson plans, semistructured interviews for teachers and parents, focus group survey questionnaires, were used to identify how primary school teachers perceive introduction of monitoring support practices and what factors have a decisive influence on their positive or negative perception of this measure.

In order to increase the validity of the survey results, a detailed review of the scientific literature on the relevant topic was conducted before developing the survey questionnaire. The Textalyser (n./d.) application was used to analyze the answers. The focus group consisted of 8 teachers ( 2 teachers from each school). The survey questionnaire consisted of 5 questions:

1) Describe the project and how you planned and implemented it in the classroom.

2) What exactly did you do in this project?

3) What benefits of participating in the project made you feel delighted about it?

4) What caused you feel negative about the project?

5) What do you propose to do to solve the problems you faced?

Data analysis

To analyze the quantitative data, they were summarized into a table, as a percentage, and calculated using the Chi-Square statistical method. In addition, the data comparison strategy (Yin, 2014), triangulation of data sources (Yin, 2014; Stake, 1995), and a study validation method (Stake, 1995) were used.

The data obtained during the focus group survey were processed using the Textalyser web tool. To process the teachers' answers to the questions, we identified the most commonly used positive words in the answers that helped us identify broad categories of answers, such as: "improvement", "quality", "motivation", "parental feedback", "learning results". The analysis was conducted taking into account the objectives of the study.

\section{Results}

The experiment was conducted under natural conditions of the educational process. The result of the project is closer, more productive and trusting collaboration between teachers, directors of studies and departments of education. Cross-attending and attending lessons by Director of Studies and Methodologist, their feedback increased the motivation, responsibility of the teachers and significantly influenced the quality of the lessons they conducted. Other teachers have also become more diligent in performing their duties, when observing the quality of performance duties by other teachers.

The calculated values for the participation of teachers in any training programs, the class, the number of pupils in the class and the number of pupils present on 
the monitoring day, attendance by Director of Studies and Methodologist using the Chi-Square statistical method are higher than the values of the Table by 0.05 , which indicates the weight of these components in monitoring support (see Table 2).

Table 2: Distribution of factors in monitoring support by weight

\begin{tabular}{|c|c|c|c|c|c|c|c|}
\hline No. & Factors & Answers of & Yes & TSE & $\mathrm{No}$ & Total & $x^{2}$ \\
\hline 1. & $\begin{array}{l}\text { Class, number of pupils } \\
\text { in the class and number } \\
\text { of pupils present on the } \\
\text { monitoring day }\end{array}$ & $\begin{array}{l}\text { Director of } \\
\text { Studies } \\
\text { Methodologist of } \\
\text { the Department } \\
\text { of Education }\end{array}$ & $\begin{array}{l}32 \\
16\end{array}$ & $\begin{array}{l}03 \\
04\end{array}$ & $\begin{array}{l}04 \\
00\end{array}$ & $\begin{array}{l}39 \\
20\end{array}$ & $\begin{array}{l}41.69^{*} \\
20.79^{*}\end{array}$ \\
\hline 2. & $\begin{array}{l}\text { Attendance of lessons by } \\
\text { Director of Studies }\end{array}$ & $\begin{array}{l}\text { Director of } \\
\text { Studies } \\
\text { Teacher }\end{array}$ & $\begin{array}{l}35 \\
18\end{array}$ & $\begin{array}{l}02 \\
01\end{array}$ & $\begin{array}{l}02 \\
01\end{array}$ & $\begin{array}{l}39 \\
20\end{array}$ & $\begin{array}{l}55.85^{*} \\
28.89^{*}\end{array}$ \\
\hline 3. & $\begin{array}{l}\text { Teacher participation in } \\
\text { any training programs }\end{array}$ & $\begin{array}{l}\text { Director of } \\
\text { Studies } \\
\text { Teacher }\end{array}$ & $\begin{array}{l}32 \\
12\end{array}$ & $\begin{array}{l}05 \\
02\end{array}$ & $\begin{array}{l}02 \\
06\end{array}$ & $\begin{array}{l}39 \\
20\end{array}$ & $\begin{array}{l}42.0^{*} \\
7.60^{*}\end{array}$ \\
\hline 4. & $\begin{array}{l}\text { Attendance of lessons by } \\
\text { Methodologist of the } \\
\text { Department of } \\
\text { Education }\end{array}$ & $\begin{array}{l}\text { Director of } \\
\text { Studies } \\
\text { Methodologist of } \\
\text { the Department } \\
\text { of Education }\end{array}$ & $\begin{array}{l}30 \\
17\end{array}$ & $\begin{array}{l}09 \\
02\end{array}$ & $\begin{array}{l}00 \\
01\end{array}$ & $\begin{array}{l}39 \\
20\end{array}$ & $\begin{array}{l}36.46^{*} \\
24.09^{*}\end{array}$ \\
\hline 5. & Cross & $\begin{array}{l}\text { Director of } \\
\text { Studies } \\
\text { Teacher }\end{array}$ & $\begin{array}{l}30 \\
14\end{array}$ & $\begin{array}{l}09 \\
02\end{array}$ & $\begin{array}{l}0 \\
04\end{array}$ & $\begin{array}{l}39 \\
20\end{array}$ & $\begin{array}{l}36.46^{*} \\
12.40^{*}\end{array}$ \\
\hline 6. & Parents survey & $\begin{array}{l}\text { Teacher } \\
\text { Parents }\end{array}$ & $\begin{array}{l}18 \\
37\end{array}$ & $\begin{array}{l}02 \\
02\end{array}$ & $\begin{array}{l}00 \\
00\end{array}$ & $\begin{array}{l}20 \\
39 \\
\end{array}$ & $\begin{array}{l}29.19^{*} \\
66.60^{*}\end{array}$ \\
\hline 7. & $\begin{array}{l}\text { Meetings of the school } \\
\text { Pedagogical Council } \\
\text { during last three months }\end{array}$ & $\begin{array}{l}\text { Director of } \\
\text { Studies } \\
\text { Teacher }\end{array}$ & $\begin{array}{l}30 \\
15\end{array}$ & $\begin{array}{l}08 \\
03\end{array}$ & $\begin{array}{l}01 \\
02\end{array}$ & $\begin{array}{l}39 \\
20\end{array}$ & $\begin{array}{l}35.23^{*} \\
15.69^{*}\end{array}$ \\
\hline
\end{tabular}

* Significant components: $d f=2 ; p=0.05$; Table value $=5.991$

As we can see from Table 2, the highest scores correspond to the answers of Directors of Studies and parents, while the values for teachers are lower, though significant and illustrative.

\subsection{The results of processing the focus group teachers' answers}

1) Describe the project and how you planned and implemented it in the classroom. All respondents completed the monitoring tasks according to the instructions and the education program.

2) What exactly did you do in this project? Analyzed their work (14 people), exchanged experience (12 people); professionally developed (14 people); (7 people) cooperated.

3) What benefits of participating in the project made you feel delighted about it? Responding to this question, teachers reported that they upgraded their professional skills (14 people), improved their teaching and self-study skills (11 teachers), increased their self-esteem and motivation (13 teachers). 
4) What caused you feel negative about the project? Answering this question, 2 out of 15 teachers indicated that they sometimes experienced problems with motivation, 4 teachers faced problems related to perception of criticism and feedback, and 1 participant of the experiment accused herself of constant procrastination.

5) What do you propose to do to solve the problems you faced? With regard to teachers' suggestions to address these issues, 1 teacher complained that this project was quite burdensome because of the additional workload, 4 teachers suggested extending the project.

In general, teachers spoke positively about the format and content of the project. Most of the teachers in the experimental group reported improvements in selforganization and self-discipline, flexibility in problem-solving, teamwork skills, and improved learning activity and learning results of their pupils. However, the respondents reported some motivation and procrastination issues, along with reluctance to criticism and feedback provided by their colleagues. Additionally, half of the focus group would appreciate it if the project was prolonged.

The results of the study made it possible to identify the conditions, limitations and factors that influence teachers' decisions regarding the implementation of monitoring support in the primary school education process.

It is interesting that the directorate of the experimental schools saw the dynamics in the teaching quality of other teachers who were not involved in the project.

\subsection{Limitations of the study}

The main limitation for this study is its participation in only four comprehensive education institutions. Others include the ownership of educational institutions and the number of teachers who participated in the experiment.

\section{Discussion}

This study goes in line with our literature review findings and contributes to the study of the problem of introducing monitoring in the educational process in primary school. First, the study broadened previous studies dedicated to motivation of pupils and increasing their learning engagement (through improving teaching skills and, accordingly, optimizing teaching and learning) (Niyivuga, Otara \& Tuyishime, 2019). Second, it enhanced the ways of continuous improving education quality (O'Mahony \& Garavan, 2012)? and the ways to motivate teaching staff (Shah \& Nair, 2012; Duan, Du \& Yu, 2018; Niyivuga, Otara \& Tuyishime, 2019). Third, this study tested the framework and principles for monitoring primary school education process and addressed the aspects of its effectiveness (Hoover, 2009; Kayani, et al, 2011; Mngomezulu, 2015; Ferdaus, 2016; Fulton, 2018).

In general, all teachers and Directors of Studies performed their duties more actively, carefully and on time. Moreover, there was a dynamic in pupil 
attendance rates and results of their educational activity. As a result of crossattending of the colleagues, attending lessons by Director of Studies and Methodologist, and providing comments and feedback, teachers noted that their motivation increased, they became more responsible in preparing for the lesson and developing educational materials.

This project also had a positive impact on the development of leadership qualities of teachers and the quality of education. Because when receiving feedback, the teacher had to respect both positive and negative feedback from a visitor (colleague, teacher or Methodologist), and since respect is a component of leadership, we can say that feedback contributed to the development of leadership qualities in teachers. With regard to quality, it is noted that when monitoring is regular, the quality (level) of teacher's pedagogical skills is improved. Teachers developed lesson plans based on the multiplicity of pupils' intelligence, and regularly encouraged pupils' performance, which increased pupils' interest in learning. In the end, this has had a small impact on the quality of pupils' education in experimental schools.

The results of the study suggest that the implementation of monitoring support at primary school is more difficult than simply attending classes and monitoring performance following ministerial recommendations.

Together with the introduction of these educational innovation practices, the participants in this study have formulated such challenges as: a) adaptation to a changed role (Durlak \& DuPre, 2008); b) establishing productive collaboration with other teachers (Fullan, 2014). The study also found that most teachers participated in the project without the necessary level of readiness for change (Fullan, 2014).

In general, this study confirmed the effectiveness of implementation of monitoring sysytem on the basis of autonomous monitoring groups by educational level. The key positive impact-factors which the involved teachers reported were a number of two-way benefits gained by both teachers and students, and improved quality of educational services, though there are still challenges to meet.

\section{Conclusions and recommendations for future research}

The study gave an idea of the initial stage of implementation of monitoring support in the educational process by primary school teachers in Ukraine.

Developing the system of the above-mentioned local monitoring system, we came to the conclusion that the priority should be given to the need to adopt a formative and non-engaged position and to establish a system that will provide useful information that will help improve the existing process on a continuous basis. In addition, our experience suggests that the success of the monitoring implementation process depends on management and its ability to make decisions and take action; the number of pupils per teacher in the class; the preliminary training of all members of the monitoring team on the basics of monitoring. 
The research conditions, limitations and contextual factors that influenced primary school teachers' perceptions of such an innovation were identified. It is found that this monitoring system helps to optimize the quality of education in primary school. The teachers noted that by participating in the project, they upgraded their professional skills, improved their pedagogical and self-study skills, increased their self-esteem and motivation. Teachers' perception of critics and recommendations is often a disincentive for educators. The results of the study are preliminary due to several limitations, which include a small number of participants, potential bias in school choice and limited opportunities for observation.

In our opinion, further research on training primary school teachers the basics of monitoring makes sense.

\section{References}

Bibik, N. M. (2017). New Ukrainian School: Teacher Guide. Pleiada Publishing House LLC.

Creswell, J. W., \& Poth, C. N. (2018). Qualitative inquiry and research design: Choosing among five approaches. Sage.

Duan, X., Du, X., \& Yu, K. (2018). School Culture and School Effectiveness: The Mediating Effect of Teachers' Job Satisfaction. International Journal of Learning, Teaching and Educational Research, 17(5), 15-25. doi:10.26803/ijlter.17.5.2

Durlak, J. A., \& DuPre, E. P. (2008). Implementation matters: A review of research on the influence of implementation on program outcomes and the factors affecting implementation. American Journal of Community Psychology, 41(3-4), 327-350. doi:10.1007/s10464-008-9165-0

Environmental Change Institute. (2014, March). A step by step guide to Monitoring and Evaluation.

https://www.geog.ox.ac.uk/research/technologies/projects/mesc/guide-tomonitoring-and-evaluation-v1-march2014.pdf

Fegan, J., \& Field, M. H. (2009). Education across Borders: Politics, Policy and Legislative Actions. Springer.

Ferdaus, J. (2016). Monitoring and Evaluation in education system of Bangladesh: Theory, reflection, and recommendation. BRAC Institute of Educational Development, BRAC University. doi:10.13140/RG.2.2.28186.54723.

Fullan, M. (2014). Teacher development and educational change. Routledge Falmer.

Fulton, C. (2018, February). Monitoring and Evaluating Policy. https://www.victoriaprimary.org.uk/cmsfiles/items/downloads/doclett20180226113324-5179/Monitoring\%20and\%20Evaluating\%20Policy.pdf

Grischenko, M. (Ed.). (2016, October). New Ukrainian School. Conceptual Principles of Secondary School Reform. https://www.kmu.gov.ua/storage/app/media/reforms/ukrainska-shkolacompressed.pdf

Hoover, J. J. (2009). RTI Assessment Essentials for Struggling Learners. Corwin Press.

$\mathrm{Hu}, \mathrm{G}$. (2002). Potential cultural resistance to pedagogical imports: The case of communicative language teaching in China. Language Culture and Curriculum, 15(2), 93-105. doi:10.1080/07908310208666636

Kayani, M. M., Begum, N., Kayani, A., \& Naureen, S. (2011). Effectiveness of monitoring system at primary level in Pakistan. International Journal of Business and Social Science, 2(19) (Special Issue), 148-154. 
Law of Ukraine \# 2145-VIII. (2017). On Education. Retrieved September 23, 2019, from https:// zakon.rada.gov.ua/laws/show/2145-19

Luginbuhl, R., Webbink, D., \& Wolf, I. (2009). Do Inspection Improve Primary School Performance? Educational Evaluation and Policy Analysis, 31(3), 231-237. doi:10.3102/0162373709338315

Marriott, N., \& Goyder, H. (2009). Manual for Monitoring and Evaluating Education Partnership. International Institute for Educational Planning.

Mertens, D. M. (2009). Research and Evaluation in Education and Psychology. SAGE Publications, Inc.

Miller, D. (2017, May 5). Importance of School Monitoring and Evaluation Systems. http://leansystemssociety.org/importance-of-school-monitoring-andevaluation-systems/

Mishra, R. C. (2005). Educational Research. A.P.H. Publishing Corporation.

Mngomezulu, N. M. (2015). Strategies of monitoring teaching and learning: A school management team perspective. $\mathrm{PhD}$ thesis. University of Kwazulu-Natal.

Niyivuga, B., Otara, A., \& Tuyishime, D. (2019). Monitoring and Evaluation Practices and Academic Staff Motivation: Implications in Higher Education Within Rwandan Context. SAGE Open. doi:10.1177/2158244019829564

Noh, H. J. (2006). Policy Evaluation system reform for efficient outcome-oriented management. Bupmunsa.

O'Mahony, K., \& Garavan, N. T. (2012). Implementing a quality management framework in a higher education organization: A case study. Quality Assurance in Education, 20, 184-200. doi:10.1108/09684881211219767.

Order of the Ministry of Education and Science of Ukraine. (2019, May 28). Procedure for Monitoring the Quality of Education. https://mon.gov.ua/storage/app/media/gromadskeobgovorennya/2019/05/28/poryadok-na-obgovorennya-1.docx

Shah, M., \& Nair, S. C. (2012). The changing nature of teaching and unit evaluations in Australian universities. Quality Assurance in Education, 20, 274-288.

Sima, S. (2006). Monitoring and Evaluation. EDU 506: Leaders as Learners: How Children and Adults Learn. Class Lecture.

Stake, R. E. (1995). The art of case study research. SAGE Publications. Textalyser. (n/d). http://textalyser.net/

Ukrainian Center for Educational Quality Assessment (UCEQA). (2017, April 26). Primary School Education Monitoring: Questions and Answers. http://testportal.gov.ua/2017/04/26/monitoring-pochatkovoyi-osvitizapitannya-i-vidpovidi/

Ukrainian Center for Educational Quality Assessment (UCEQA). (2018, April 27). Monitoring the Quality of Primary Education: Pupil Questionnaires. http://testportal.gov.ua/2018/04/27/monitoryng-yakosti-pochatkovoyi-osvityuchnivski-ankety/

Ukrainian Center for Educational Quality Assessment (UCEQA). (n./d.). Examples of Questionnaires for Fourth-Formers. PIRLS, TIMSS. https://drive.google.com/drive/u/0/folders/18HJGpLz2gzTjHfoJiHSZTcwVCvMPozv

Yin, R. K. (2014). Case study research: design and methods. Sage. 